\title{
THE MEETING OF EAST AND WEST ON THE JAPANESE SCENE
}

\author{
Tetsutaro ARIGA \\ Shoin Junior College, Kobe
}

\section{Introduction:}

About the fact that East and West are actually meeting in Japan there can be no dispute. But when we are asked just how they are meeting or what is the significance of the fact for the present and future of Japan as well as of the world, different answers may be offered. My own approach is to study our subject by singling out certain mental traits of the Japanese that seem to have great bearing on the matter. I will discuss them under the following five headings: 1 . flexibility, 2. selectivity, 3. comprehensiveness, 4. love of forms, 5. zeal for specialization.

1. Flexibility:

It is impossible for us to discuss Japanese culture without reference to a series of foreign influences. These came in first from Korea and China, then from Portugal and Spain. Even to the closed Japan of the Tokugawa period some Dutch influences reached, though in an extremely limited way. Since 1858, and on a larger scale since 1868, both the government and the people of Japan have been positively taking in western civilization. So if you take any aspect of Japanese culture and analyze it into its component factors, you may get a number of foreign influences and nothing else. Is Japanese culture, then, merely a product of slavish imitation? It is undeniable that there are plenty of imitations and copies of foreign patterns; but it is not entirely correct to say that the Japanese mind is but a passive recipient. For it seems that it has always been at work selecting, accepting, combining, adapting, and assimilating various cultural elements coming from outside.

Such a mentality may be better characterized by calling it flexible than by calling it imitative. It is always sensitive-sometimes too much so--to what is going on in other parts of the civilized world and is ever ready to respond to whatever new cultural stimuli come in.

\section{Selectivity:}

Althouth the Japanese mind has accepted many foreign cultural influences, it has not done so without discrimination. A number of motives may be found for each act of selection, but generally speaking, political and utilitarian motives loom large. For instance, when Francis Xavier brought Christianity in the mid-sixteenth century it was welcomed by certain daimyos who desired to have trade relations established with the western powers. But in 1587 Toyotomi Hideyoshi banned the missionaries while still wanting to deal with the western merchants. Still later, discovering that it was impossible to continue foreign trade and shut out Christianity, the Tokugawa government decided to get rid of both, and closed the door of the country. 
The same sort of attitude may be observed with regard to the period around and subsequent to the Meiji Restoration of 1868 . Since the government strongly felt the need of making Japan a modern nation, they welcomed above all science and techniques. But they believed Japan had enough religious and moral heritage, and tried to avoid Christian influences as much as possible. As a result, the kind of western civilization Japan has accepted may be called "western civilization minus Christianity". Western ideas and methods were received only in so far as they could contribute toward making the country strong and prosperous under the emperor system.

The collapse of this system in consequence of the last war has caused great vacillation of mind. While the majority take the western type of democracy seriously, there are also people who are attracted by the Soviet way of socialization. Some especially among younger people, have gone over to nihilism; but perhaps a larger number of them are finding their satisfaction in dialectical materialism or in existentialism. On the other hand, there seem to be more people than before who are interested in Christianity. At least, there is today any prejudice against Christianity except in rural areas; and there is a growing number of people who seriously are trying to understand it as a basic historic factor of western civilization.

\section{Comprehensiveness:}

First from the continent of Asia, later from Europe and America, Japan has adopted various cultural elements during the last fifteen centuries. In the course of time they have been so well amalgamated that you may call our culture here Japanese culture despite the variety of sources that supplied its elements. Yet there has never been developed a logically consistent system of culture. It often happens that some mutually contradictory ideas are held without any regard to logical consistency. For centuries the Japanese have believed in both Shinto and Buddhism. Today you may come across a young person in whom Nietzscheism, Marxism, Kierkegaardianism, and Zen-Buddhism all co-exist! He may call himself a Buddhist or even a Christian. But that perhaps does not mean much. He should rather be called a typical Japanese, as long as he is not bothered by the inconsistency of ideas and thoughts that are in his mind.* In other words, his mind works intuitively rather than rationally.

Of course we have more consistent Shintoists, or Buddhists, or Christians, and that some real intolerant ones, too. But on the whole Japanese people are broad-mind and tolerant. Just as they enjoy eating sashimi, shmmai, and beefsteak, drinking beer, sake, wine, and even whisky, in one and the same meal, they take pride in the richness of ideas coming from all quarters rather than in the consistency with which these are combined or selected. This is what I mean when I say the Japanese mind is comprehensive.

\footnotetext{
* By saying this 1 do not mean that religious belief does not make any difference. There is actually some recognizable difference in thought and behavior between Christian and non-Christian Japanese. My analysis, however, may help those who are interested in Christian missions in this country see deeper into the roots of their problems.
} 


\section{Love of Forms:}

The most creative aspect of the Japanese mind may perhaps be found in its aesthetic activities. It is fond of discovering forms everywhere. Thus quite formalized manners and etiquette have been developed, to which every cultured person is expected to conform. Thus the ordinary custom of tea-drinking has been refined into an elaborate tea-ceremony. In a similar way the act of arranging flowers for ornamental purposes has developed into the art of ikebana. The person who first discovered or set certain forms becomes the founding master of a school. This tendency is recognizable in almost every department of our culture. You will find there schools, masters, and their successors. And the order of succession is in many cases hereditary. Whether it is tea-ceremony, flower-arrangement, poetry, painting, music, swimming, fencing, horsemanship, religion, or philosophy, it is a master-pupil relationship that has preserved the original forms of a great rounding master in the field.

This cultural tendency has certainly been a cause of much conventionalism from which today we Japanese are trying hard to free ourselves. But it should be noted that the Japanese love of forms is not in itself identical with formalism. On the contrary, the original forms taught by a master are results of his creative imagination and abstraction. And the pupils who have mastered them can thereby penetrate into the spirit of the master who produced them. Forms then become symbols to which certain mystic qualities are attached. Then they cease to be mere externals. Today this sort of master-pupil relationship is often called feudalistic. But even those who consider themselves enlightened intellectuals are fond of talking about "schools". Whenever they meet a historian or a philosopher from abroad, the first question they ask is likely to be, "To which school do you belong?" or "Whose theory are you expounding?"

\section{Zeal for Specialization:}

Closely related to the love of forms is a zeal for specialization. For one's love of forms makes him strive after refinement and perfection; and the shortest way to attain them is to concentrate his mind and energy on one thing. A painter like the late Sotaro Yasui who did not want to know anything outside his own domain of painting is sure to be an object of admiration. Indeed versatility is also admired and there is no lack of versatile persons in this country. But a scholar, for instance, who has devoted his whole life exclusively to a certain particular line of study to the neglect of everything else in the world is more likely to be acclaimed as a truly scholarly person.

Specialization is of course important for cultural progress, but too much emphasis on it may easily breed sectionalization. To take the case of a university, specialization tends to make the mutual contact of scholars of different lines more and more difficult. Love of specialization, moreover, may also tempt people to minimize or even disregard broader common grounds. I recall a story, which I heard more than thirty years ago, of a Japanese boy studying in America. He wanted to earn some dollars by getting a cooking job in a home. So he went to a triend of his, also a Japanese, and asked him to teach him how to cook. The latter said: "The most important part of cooking is pie-making. If you 
can bake an excellent pic, you will immediately be recognized as an expert cook. And the most important part of a pie is its crust. So I'll teach you how to make a good crust." then showed him a recipe for pie crust and let him try it. The student finally succeeded in baking a good crust. So he went to home where he was hired as cook. But he was greatly embarrassed when he realized that he had learned only the making of a crust but knew nothing about preparing the filling!

I think this story eloquently reveals a characteristic trait of Japanese mentality. Japanese people have often a good understanding of the most subtle parts of western culture but do not want to pay much attention to what is more commonplace and elementary. They may have learned to make an excellent pie crust but do not always think the making of fillings is important.

\section{Conclusion:}

I have not discussed the meeting of East and West in Japan as a problem of Buddhism vs. Christianity or Confucianism vs. Greek philosophy. For both Buddhism and Confucianism were also originally alien to the Japanese mind. Rather I have tried to call attention to certain traits which seem to me inherent in it. I do not by any means pretend to be exhaustive. But these five traits may be enough to start a discussion. Of course, we have to rethink the problem in view of the total situation in which present Japan is placed. Now that old authorities have fallen to the ground, the Japanese mind has no criterion ready whereby it may appraise things coming from outside and re-appraise things that are already here. However, it has to find out its own way. So we have to see whether these five traits can yet have their functions in this democratic age. As I see it, they are in themselves not necessarily undemocratic, although they have acquired in the course of history feudalistic coloring. But I think it is equally true that they have no positive power to produce a democracy. We see that at the root of western democracy there are the Greek logos and the Hebraic-Christian sense of personal commitment. These ought to be more thoroughly understood and appropriated by the Japanese. But this will not mean the destruction of these five traits of mind. Flexibility, selectivity, comprehensiveness, and the love of perfection and subtlety will all find their places in a new democratic setting and will be able to produce genuincly good things for the future of mankind.

Tetsutaro Ariga (有賀鉄太郎 1899- ) Litt. D. (Kyoto Univ.), Th. D. (Union Theol. Sem.), D. D. (Chicago Divinity School). President, Shoin Junior College, Kobe. Formerly Prof. of Christianity at Doshisha Univ. and then Kyoto University.

Reprinted from Japanese Religions, 1959, 1, 4-9, with the agreement of the writer and the editor. 